\title{
Article
}

\section{Selective Recovery of Lithium Ion in Saline Water Using}

\section{A Novel $\lambda-\mathrm{MnO}_{2}$ Adsorbent}

\author{
Kazuharu YOSHIZUKA and Takuya SUZUKI \\ Department of Chemical Processes and Environments, The University of Kitakyushu, Hibikino 1-1, Kitakyushu \\ 808-0135, Japan
}

Katsutoshi INOUE

Department of Applied Chemistry, Saga University, Honjyo 1, Saga 840-8502, Japan

(Manuscript submitted February 15, 2003; accepted March 26, 2003)

\begin{abstract}
A novel $\lambda$-type manganese dioxide $\left(\lambda\right.$ - $\left.\mathrm{MnO}_{2}\right)$ adsorbent has been developed for selectively recovering $\mathrm{Li}^{+}$from seawater. This adsorbent can be prepared from spinel-type lithium di manganese tetra oxide $\left(\mathrm{LiMn}_{2} \mathrm{O}_{4}\right)$ using ion exchange of $\mathrm{Li}^{+}$by hydrogen ion. In batchwise adsorption, $\lambda-\mathrm{MnO}_{2}$ adsorbent can effectively adsorb $\mathrm{Li}^{+}$in high $\mathrm{pH}$ region like seawater $(\mathrm{pH}$ $=8.1$ ) with quite high selectivity more than 800 molar ratio of $\mathrm{Li}^{+} / \mathrm{Na}^{+}$. In chromatographic separation, $\mathrm{Li}^{+}$can effectively adsorbed on the adsorbent packed into column, while $\mathrm{Na}^{+}$is scarcely adsorbed in adsorption stage. In elution stage, $\mathrm{Li}^{+}$can be concentrated more than 50 times compared with initial lithium concentration in feed solution of adsorption stage, while little $\mathrm{Na}^{+}$was eluted. The selectivity of $\mathrm{Li}^{+} / \mathrm{Na}^{+}$can be achieved to 1500 times in molar base.
\end{abstract}

\section{Introduction}

Since there are many components dissolved in the saline water, and the recovery of the components have been noticed from viewpoint of the size of the absolute contents. However, though the element concentrations in saline water are generally very low, it is few available industrial scale recovery except for potassium, bromine, magnesium, sodium chloride. Since the concentration of lithium, a target ion this study, in the saline water is quite high $(0.18 \mathrm{ppm}$ in average[1]) compared with uranium, the recovery of lithium from the saline water is promising application for securing of resources of large-capacity battery and material of the light alloy for the aircraft or nuclear fusion fuel etc. In order to develop the effective recovery process of lithium, the adsorbents having selectivity for lithium ion from high-dense coexistence sodium ion ( $>10000 \mathrm{ppm}$ ) should be necessary.

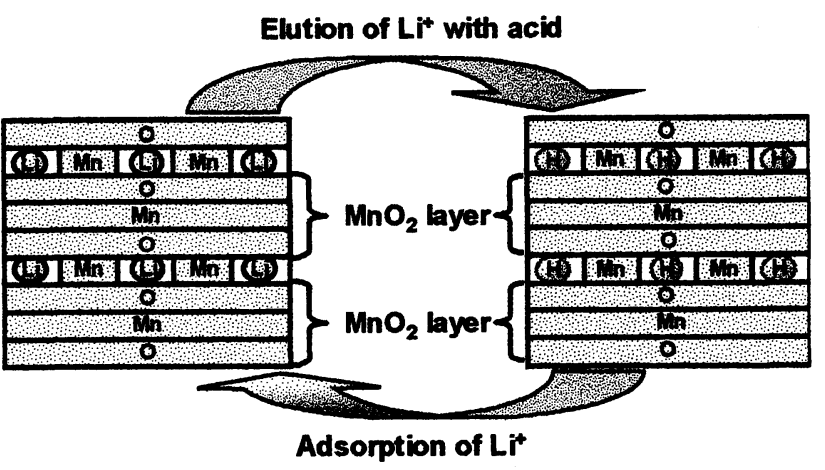

Fig. 1. Schematic diagram of adsorption and elution mechanism of $\mathrm{Li}^{+}$in $\lambda-\mathrm{MnO}_{2}$ adsorbent 
In this study, $\lambda$-type manganese dioxide $\left(\lambda-\mathrm{MnO}_{2}\right)$ has been studied as a novel type adsorbent for lithium recovering from saline water. This adsorbent can be prepared by elution of lithium from spinel type lithium di-manganese-tetra-oxide $\left(\mathrm{LiMn}_{2} \mathrm{O}_{4}\right)$ with aqueous hydrochloric acid. Figure 1 shows the schematic diagram of adsorption and elution of lithium in $\lambda-\mathrm{MnO}_{2}$ adsorbent. Since $\lambda-\mathrm{MnO}_{2}$ consists of both ion-exchangeable pillared-manganese layer and structural $\mathrm{MnO}_{2}$ layer, $\mathrm{H}^{+}$can be exchanged by $\mathrm{Li}^{+}$without breaking the crystal structure because pillared-manganese can support $\mathrm{MnO}_{2}$ layer.[2-4]

We investigated the adsorption of lithium ion in the solution coexisting high concentration sodium ion. We also investigated the column selective concentration of lithium ion from model saline water.

\section{Experimental}

\subsection{Preparation of $\lambda-\mathrm{MnO}_{2}$ adsorbent}

Powders of $\mathrm{Mn}_{3} \mathrm{O}_{4}(20.0 \mathrm{~g}, 0.088 \mathrm{~mol})$ and $\mathrm{LiOH} \cdot \mathrm{H}_{2} \mathrm{O}(5.61 \mathrm{~g}, 0.132 \mathrm{~mol})$ were mixed and ground for $15 \mathrm{~min}$. Here, we set the mixing ratio of powders to molar ratio of $\mathrm{Mn} / \mathrm{Li}=2$. The mixture was sintered at $425^{\circ} \mathrm{C}$ for $5 \mathrm{~h}$ with an electric oven. After slow cooling at room temperature for $1.5 \mathrm{~h}$, the sintered mixture was mixed and ground again for $15 \mathrm{~min}$. The mixture was also sintered at $500^{\circ} \mathrm{C}$ for $5 \mathrm{~h}$ with an electric oven. After slow cooling in electric oven for $12 \mathrm{~h}$, spinel type $\mathrm{LiMn}_{2} \mathrm{O}_{4}$ was obtained as an intermediate product.

The product was treated 5 times for overnight with $1.0 \mathrm{~mol} / \mathrm{dm}^{3} \mathrm{HCl}$ solution to obtain $\lambda-\mathrm{MnO}_{2}$ adsorbent. To keep the spinel type of crystal structure, we treated the powder of $\mathrm{LiMn}_{2} \mathrm{O}_{4}$ with aqueous $\mathrm{HCl}$ solution. Here, we set the volume of $\mathrm{HCl}$ solution to keep more than 40 of molar ration of $\mathrm{H}^{+}$to $\mathrm{Li}^{+}$. We observed the crystal structure of $\lambda-\mathrm{MnO}_{2}$ after each acid treatment with $\mathrm{X}$-ray powder diffractometer. The content of $\mathrm{Li}^{+}$in $\lambda-\mathrm{MnO}_{2}$ was calculated by the summation of the concentration of $\mathrm{Li}^{+}$in each $\mathrm{HCl}$ solution treated, which concentration was measured by an atomic absorption spectrophotometer (AAS).

\subsection{Batch adsorption of metal ion}

The adsorbent $\left(20 \mathrm{mg}\right.$ ) was shaken with $0.1 \mathrm{~mol} / \mathrm{dm}^{3} \mathrm{NH}_{4} \mathrm{Cl}-0.1 \mathrm{~mol} / \mathrm{dm}^{3} \mathrm{NH}_{4} \mathrm{OH}$ aqueous buffer solution $\left(10 \mathrm{~cm}^{3}\right)$ of various $\mathrm{pH}$ containing different concentrations of $\mathrm{Li}^{+}$and $\mathrm{Na}^{+}$. All batch experiments were carried out at $30^{\circ} \mathrm{C}$ for $2 \mathrm{~h} \mathrm{Li}^{+}$and $\mathrm{Na}^{+}$concentrations before and after equilibria were measured by AAS.

Adsorption amount of metals on adsorbent, $q_{\mathrm{M}}[\mathrm{mmol} / \mathrm{g}]$, is calculated by:

$$
q_{\mathrm{M}}=\left(C_{\mathrm{M} 0}-C_{\mathrm{M}}\right) \cdot L / w \quad\left(\mathrm{M}=\mathrm{Li}^{+}, \mathrm{Na}^{+}\right)
$$

where $C_{\mathrm{M} 0}$ and $C_{\mathrm{M}}$ are initial and equilibrium concentrations of $\mathrm{M}$ ions in the aqueous phase $\left[\mathrm{mmol} / \mathrm{dm}^{3}\right], L$ is volume of aqueous solution $\left[\mathrm{dm}^{3}\right]$, and $w$ is weight of adsorbent $[\mathrm{g}]$.

\subsection{Chromatographic separation and concentration of lithium ion}

The adsorbent $(3.0 \mathrm{~g})$ was packed into the column tube $(10 \mathrm{~cm})$, together with cotton and glass beads $(1 \mathrm{~mm}$ diameter) to be sandwiched. Wet volume of the adsorbent in the column was $6.0 \mathrm{~cm}^{3}$. The aqueous solution was flow upward to the column with micro tube pump. Flow rate of the feed solution was $0.8 \mathrm{~cm}^{3} / \mathrm{min}$. In the column adsorption stage, feed solution was $0.1 \mathrm{~mol} / \mathrm{dm}^{3} \mathrm{NH}_{4} \mathrm{Cl}-0.1 \mathrm{~mol} / \mathrm{dm}^{3} \mathrm{NH}_{4} \mathrm{OH}$ aqueous buffer solution $(\mathrm{pH}=8.1$ ) containing both $40 \mathrm{ppm}$ of $\mathrm{Li}^{+}$and $\mathrm{Na}^{+}\left(\left[\mathrm{Li}^{+}\right]=5.7 \mathrm{mmol} / \mathrm{dm}^{3}\right.$, and $\left[\mathrm{Na}^{+}\right]=1.7 \mathrm{mmol} / \mathrm{dm}^{3}$, respectively). In the column elution stage, feed eluting solution was 1.0 and $0.1 \mathrm{~mol} / \mathrm{dm}^{3} \mathrm{HCl}$ solution. After break through of metal ions from the column in the adsorption stage, deionized water was fed owing to wash out the feed solution from the column. Then eluting solution was fed into the column of the adsorbent loaded $\mathrm{Li}^{+}$and $\mathrm{Na}^{+}$in the adsorption stage. The effluent was collected with fraction collector, to measure the concentrations of metals by AAS.

Bed volume, B.V., is calculated by:

$$
\text { B.V. }=v \cdot t / V
$$


where $v$ is flow rate of solution [ $\mathrm{cm}^{3} / \mathrm{min}$ ], $t$ is supplying time of feed solution [min], and $V$ is wet volume of adsorbent $\left[\mathrm{cm}^{3}\right]$.

\section{Results and Discussion}

\subsection{Characteristics of $\lambda-\mathrm{MnO}_{2}$ adsorbent}

Figure 2 shows XRD patterns of $\mathrm{LiMn}_{2} \mathrm{O}_{4}$ and 5 kinds of the intermediate $\lambda$ - $\mathrm{MnO}_{2}$ after each acid treatment with $1.0 \mathrm{~mol} / \mathrm{dm}^{3} \mathrm{HCl}$ solution. The closed circles in the figure indicate the peaks of spinel structure. Since the XRD pattern of each treated $\lambda-\mathrm{MnO}_{2}$ is quite good agreement with spinel type $\mathrm{LiMn}_{2} \mathrm{O}_{4}$, the spinel crystal structure of $\lambda-\mathrm{MnO}_{2}$ can be completely kept until 5 times treatment. $[5,6]$ The lattice constants of $\lambda-\mathrm{MnO}_{2}$ are $\mathrm{a}=0.799 \mathrm{~nm}, \mathrm{~b}=$ $0.804 \mathrm{~nm}, \mathrm{c}=0.803 \mathrm{~nm}, \alpha=89.9^{\circ}, \beta=89.7^{\circ}$ and $\gamma$ $=89.9^{\circ}$, respectively. The crystal structure of $\lambda-\mathrm{MnO}_{2}$ is almost cubic system in which $\mathrm{b}$ and $\mathrm{c}$ axes expand a little.

$96.4 \%$ of $\mathrm{Li}^{+}$was eluted from the $\mathrm{LiMn}_{2} \mathrm{O}_{4}$ by 5 times acid treatment, that is, the product of $\lambda-\mathrm{MnO}_{2}$ is $\mathrm{Li}_{0.036} \mathrm{Mn}_{2} \mathrm{O}_{4}$.

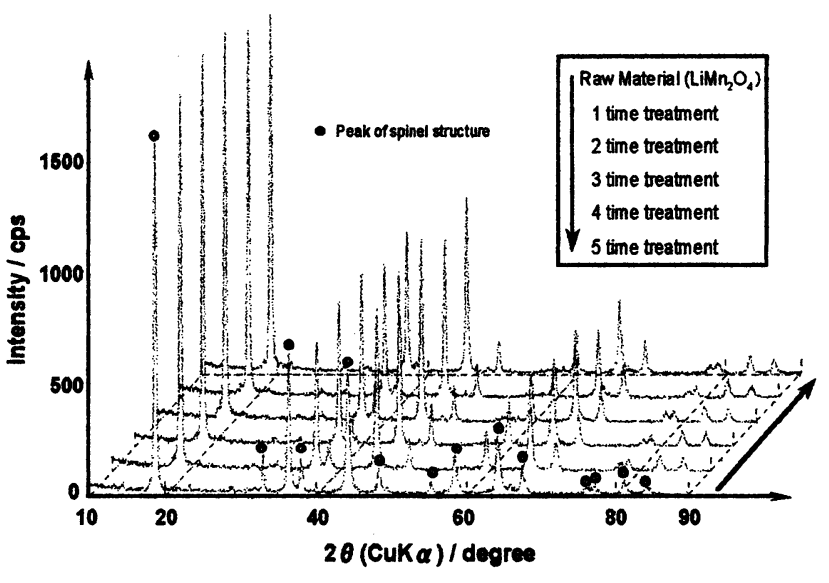

Fig.2. XRD patterns of $\mathrm{LiMn}_{2} \mathrm{O}_{4}$ and the intermediates $\lambda-\mathrm{MnO}_{2}$ during the acid treatment

\subsection{Batch adsorption of metal ion}

Figure 3 shows $q_{\mathrm{Li}}$ vs. $\mathrm{pH}$ of aqueous solution at equilibrium. This adsorbent has high adsorption ability of $\mathrm{Li}^{+}$ in high $\mathrm{pH}$ region. In particular, since the $\mathrm{pH}$ of seawater is 8.1 , this adsorbent can effectively adsorb $\mathrm{Li}^{+}$from seawater.

Figure 4 shows $q_{\mathrm{Li}}$ vs. molar ratio of $\mathrm{Na}^{+} / \mathrm{Li}^{+}$in aqueous solution. Here, we cannot set the molar ratio of $\mathrm{Na}^{+} / \mathrm{Li}^{+}$exceeding 800 , because the solubility of sodium chloride in $0.1 \mathrm{~mol} / \mathrm{dm}^{3} \mathrm{NH}_{4} \mathrm{Cl}-0.1 \mathrm{~mol} / \mathrm{dm}^{3} \mathrm{NH}_{4} \mathrm{OH}$

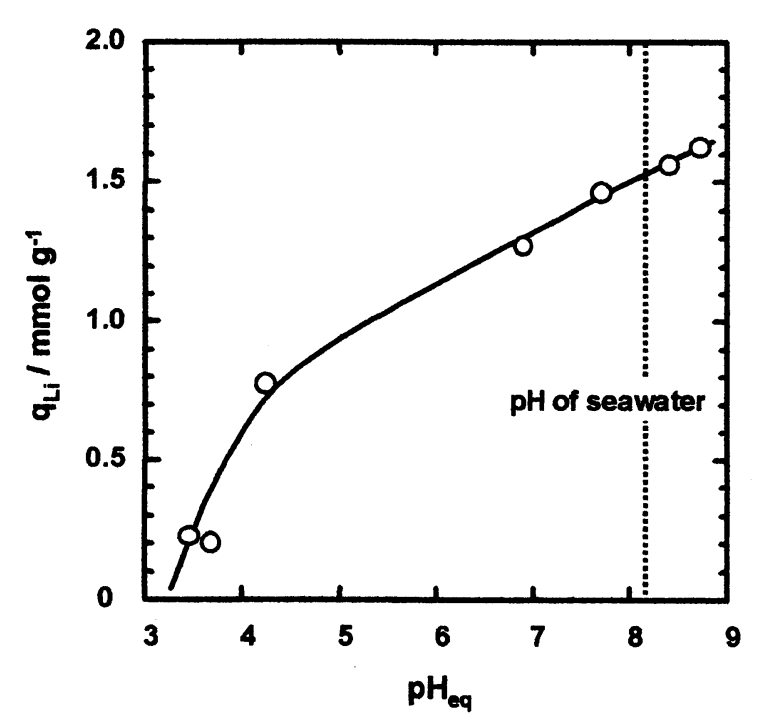

Fig.3. Adsorption amount of lithium on adsorbent, $q_{\mathrm{Li}}$, vs. $\mathrm{pH}$ of aqueous solution at equilibrium, $c_{\text {Li } 0}=0.029 \mathrm{mmol} / \mathrm{dm}^{3}(=0.2 \mathrm{ppm})$

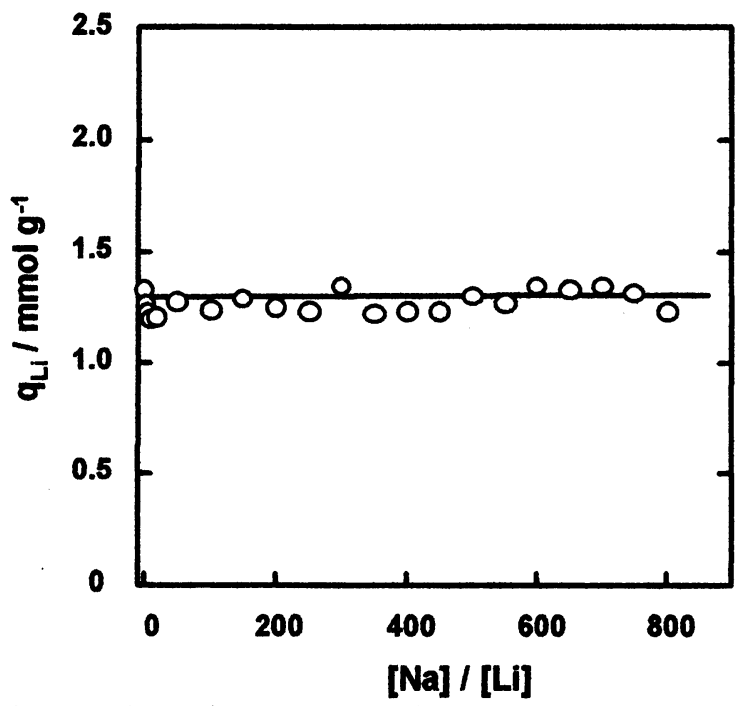

Fig.4. Adsorption amount of lithium on adsorbent, $q_{\mathrm{Li}}$, vs. molar ratio of $\mathrm{Na}^{+} / \mathrm{Li}^{+}$in aqueous solution, $c_{\mathrm{Li} 0}=0.029 \mathrm{mmol} / \mathrm{dm}^{3}$ (=0.2 $\mathrm{ppm}$ ) 
aqueous buffer solution is limited to $4.0 \mathrm{~mol} / \mathrm{dm}^{3}$. Since no influence on $\mathrm{Li}^{+}$adsorption was observed until 800 times higher concentration of $\mathrm{Na}^{+}$, it is elucidated that quite high selectivity for $\mathrm{Li}^{+}$vs. $\mathrm{Na}^{+}$(molar ratio of $\mathrm{Li}^{+} / \mathrm{Na}^{+}$ exceeding 800) can be achieved using this $\lambda-\mathrm{MnO}_{2}$ adsorbent. This separation coefficient is 1.5 times greater than the same kinds of $\mathrm{MnO}_{2}$ adsorbents in the previous papers by Ooi et al..[2-4]

\subsection{Chromatographic separation and concentration of Lithium ion}

Figure 5 (a) and (b) shows the break through profile of $\mathrm{Li}^{+}$and $\mathrm{Na}^{+}$and the elution profile of $\mathrm{Li}^{+}$and $\mathrm{Na}^{+}$from the metal-loaded adsorbent in the column adsorption stage (metal concentration vs. B.V.), respectively. Breakthrough times of $\mathrm{Li}^{+}$and $\mathrm{Na}^{+}$are $43 \mathrm{~h}$ and $5 \mathrm{~min}$, respectively. $\mathrm{Li}^{+}$can effectively adsorb on the adsorbent packed into column, while $\mathrm{Na}^{+}$is scarcely adsorbed. $\mathrm{Li}^{+}$can be concentrated up to $2680 \mathrm{ppm}\left(386 \mathrm{mmol} / \mathrm{dm}^{3}\right)$, while only $5.9 \mathrm{ppm}\left(0.257 \mathrm{mmol} / \mathrm{dm}^{3}\right)$ of $\mathrm{Na}^{+}$was eluted, without dissolving manganese in the adsorbent. From these results, it can be calculated that the molar selectivity of $\mathrm{Li}^{+}$vs. $\mathrm{Na}^{+}$can be achieved to 1500 times. This separation coefficient is the best in the previous published works.

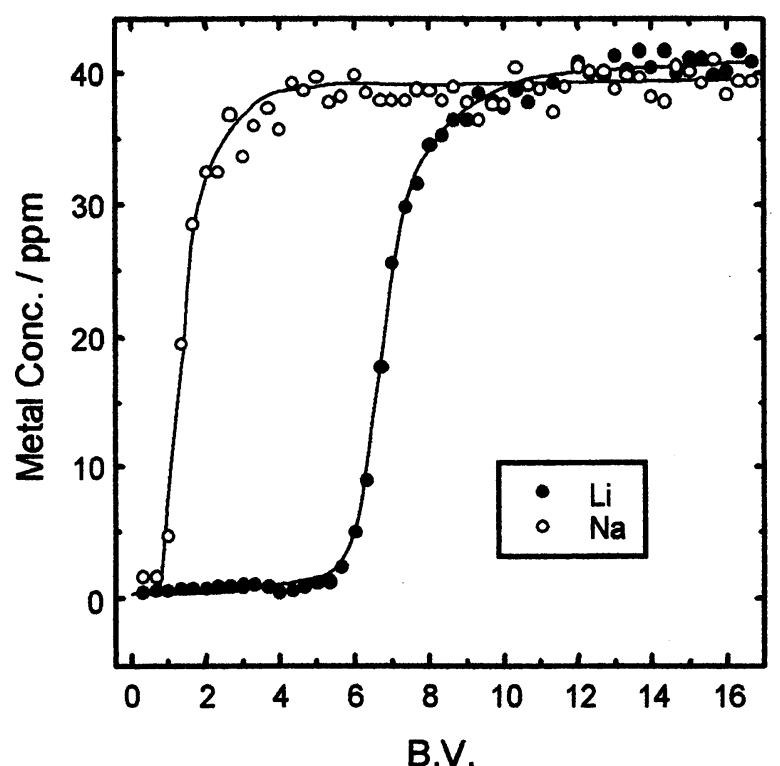

Fig.5. Break through profile (a) and Elution profile (b) of $\mathrm{Li}^{+}, \mathrm{Na}^{+}$and $\mathrm{Mn}$

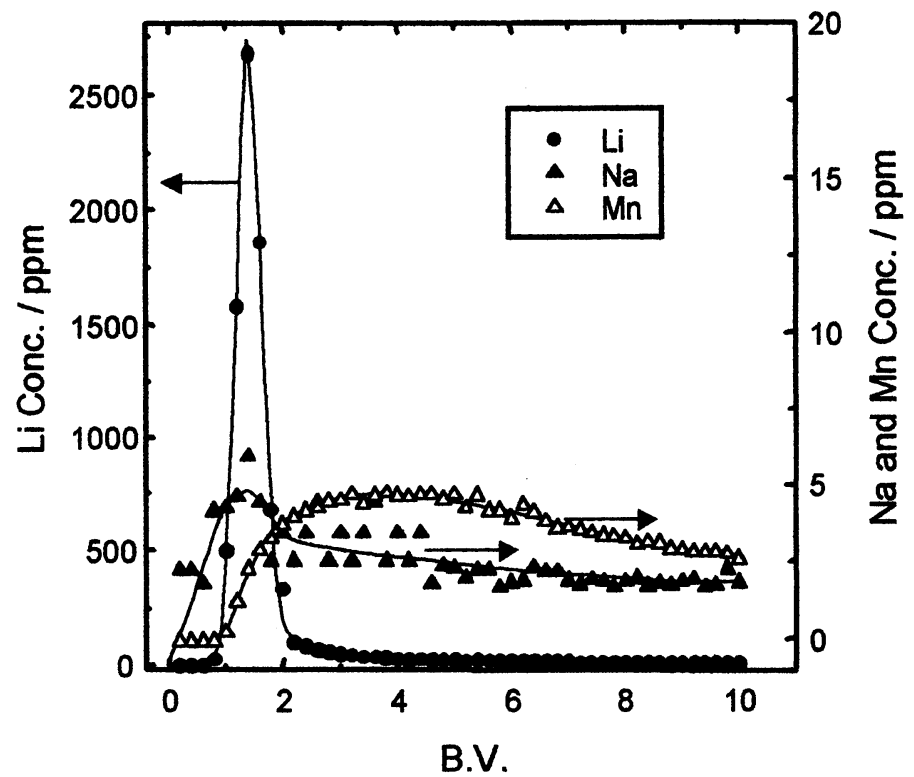

\section{Acknowledgments}

The present work is supported by Grant-in-Aids for Scientific Research and for $21^{\text {st }}$ Century COE Program from the Ministry of Education, Science, Sports and Culture of Japan and by a grant from Kurita Water and Environment Foundation.

\section{References}

1) E. Kunugita, J. H. Kim, I. Komasawa, Kagaku Kogaku Ronbunshu, 16, 1045-1051 (1990).

2) K. Ooi, Y. Miyai, S. Katoh, H. Maeda, M. Abe, Chem. Lett., 1988, 989-992.

3) K. Ooi, Y. Miyai, S. Katoh, H. Maeda, M. Abe, Langmuir, 5, 150-157 (1989).

4) K. Ooi, Y. Miyai, J. Sakakihara, Langmuir, 7, 1167-1171 (1991).

5) W. Tang, H. Kanoh, K. Ooi, J. Solid State Chem., 142, 19-28 (1999).

6) A. Tanaka, H. Tamura, R. Furuichi, Electrochem., 67, 974-977 (1999). 